\title{
VYUŽITIE MULTIKRITERIÁLNEJ ANALÝZY V INTEGROVANOM MANAŽMENTE POVODŇOVÉHO RIZIKA
}

\author{
Lukáš Michaleje
}

\begin{abstract}
Floods represent the most destructive and most occurring natural hazard in Slovakia and it is necessary to advert full attention from scientific community, policy makers and population. This paper is focused on the integrated flood risk management and issues connected with it. In first section we describe drivers of the change in perception of flood risk and impact on its management. Next, we define core principles of integrated flood risk management, and characterize objective and spatial aspect. In the final part we are focused on multicriteria analysis. This decision support system, provide best methods in support of choosing best alternative to decreasing flood risk. Characteristic of all steps included in multicriteria analysis is followed by examples from works, that use it as decision support system in flood risk management related issues.
\end{abstract}

Keywords: floods, integrated flood risk management, decision support system, multicriteria analysis

\section{Úvod}

Povodne sú prírodným fenomén, ktorého výskum prešiel v posledných desat'ročiach transformáciou. Jednorozmerné chápanie povodňového rizika presadzovalo hlavne zníženie pravdepodobnosti zaplavenia územia (Estman et al. 1997). Tradičný inžiniersky prístup sa tak sústred'oval na ochranu pred povodňami a hlavným dôsledkom bola najmä výstavba technických opatrení. Rozsiahle škody po povodniach aké boli napr. na Odre (1997), Labe (2002), Dunaji (2006), alebo vo Vel'kej Británii (2007) boli jedným s dôvodov zmeny vnímania povodňového rizika. Počas týchto katastrof došlo k prekročeniu limitov technických opatrení, ktoré vytvárali klamlivý pocit bezpečia. Vysoké škody spôsobené týmito povodňami teda neboli dôsledkom len samotného zaplavenia, ale aj náchylnosti objektov $\mathrm{v}$ ohrození na poškodenie. Na základe týchto zistení sa začalo na povodňové riziko pozerat' z nového uhla pohl'adu (Hall, Penning-Rowsell, 2011, Kousky, Walls, 2014). Nové vnímanie rizika presadzovalo názor, že škody nespôsobovala len pravdepodobnost' výskytu povodne (ohrozenie), ale aj náchylnost' na poškodenie (zranitel'nost') a vystavenie sa riziku (expozícia) (Gouldby, Samuels, 2005, Bouma et al., 2005, Solín, 2015). Viacrozmerné chápanie povodňového rizika teda môžeme vyjadrit', ako kombináciu hazardu, zranitel'nosti a expozície (Merz et al., 2010, IPCC, 2012, Koks et al., 2015). Nový 
pohl'ad na povodňové riziko priniesol aj zmenu v jeho hodnotení a taktiež aj v manažmente. Pri hodnotení povodňového ohrozenia sa okrem vybreženia vodného toku, dostáva do pozornosti aj ohrozenie $\mathrm{z}$ vody stekajúcej po svahoch alebo povodne z kanalizačných sietí. Okrem ohrozenia je rovnaká pozornost' venovaná aj výskumu a hodnoteniu zranitel'nosti ekonomického, sociálneho a environmentálneho systému. Do popredia sa dostáva nový hodnotový systém spoločnosti, ktorý poukazuje na zvýšenú ochranu ekosystémov, decentralizáciu zodpovednosti za vodné toky a manažment povodňového rizika ako aj aktívne zapojenie verejnosti do procesu rozhodovania. Tieto koncepty boli zahrnuté do integrovaného manažmentu povodňového rizika, ktorý kontinuálne rieši problematiku redukcie povodňového rizika komplexne v celom povodí, za spolupráce všetkých dotknutých strán. Ciel'om nášho príspevku je priniest' komplexný pohl'ad na integrovaný manažment povodňového rizika, jeho definície a koncepcie. Ďalším ciel'om je objasnit' problematiku rozhodovania v redukcií povodňového rizika za pomoci multikriteriálnej analýzy.

\section{Integrovaný manažment povodňového rizika a jeho princípy}

Pre integrovaný manažment povodňového rizika existuje viacero definícií. Najvhodnejšiu charakteristiku však ponúka WMO, GWP (2004): Integrovaný manažment povodňového rizika je proces, ktorý uprednostñuje holistický prístup k manažmentu povodňového rizika. Spája vodné a krajinné zdroje, rozvoj v povodí vkontexte integrovaného manažmentu vodných zdrojov a má za ciel' maximalizovat' výhody z využivania inundačných území a minimalizovat' straty na životoch spôsobené povodñami.

Táto definícia nám poukazuje na viacero princípov, ktoré sú pre integrovaný manažment povodňového rizika vlastné. Prvým je holistický prístup. Do problematiky povodní sa okrem hydrológie a vodného hospodárstva zapájajú aj vedecké disciplíny ako územné plánovanie, geografia, environmentalistika, meteorológia, ale aj inštitúcie štátnej správy a samosprávy. V neposlednom rade sa zapájajú aj ohrození obyvatelia a subjekty hospodáriace v ohrozenom území (cf. McFadden et al., 2009). Práve spôsob zapojenia obyvatel'ov do hodnotenia povodňového rizika je dôležitý element, ktorý poukazuje na výhody oproti tradičnému inžinierskemu prístupu. Je potrebné aby obyvatelia zhodnotili svoju percepciu povodňového rizika. Takýmto spôsobom je možné zhodnotit' informovanost' a pripravenost' obyvatel'ov. Okrem percepcie je potrebné získat' aj názor obyvatel'ov na riešenie problematiky. Pri zapájaní jednotlivých aktérov a stakeholdrov je využívaný prístup zdola nahor (bottom up) princíp. Všetky zúčastnené strany ako aj stakeholdri a obyvatelia sú zapojení do redukcie povodňového rizika od začiatku (Filho, 2013).

Ďalším princípom, na ktorom je postavený integrovaný manažment povodňového rizika je decentralizácia. Zodpovednost' za redukciu povodňového 
rizika by mala byt' distribuovaná na nižšie úrovne tak aby obce boli zodpovedné za rozhodovanie o najlepšej alternatíve podla vlastných preferencií. Pri tomto procese je potrebné dat' možnost' vyjadrit' svoj názor všetkým aktérom, ktorých sa povodne dotýkajú (Wehn et al., 2015). Dosah povodní presahuje hranice administratívnych jednotiek. Pre spoločný úžitok so spolupráce pri zmierňovaní povodňových škôd, musia samosprávy spolupracovat', a to za pomoci hierarchicky vyššej jednotky, ktorá usmerňuje ich činnost' (Diepernik et al., 2013). Integrovaný manažment povodňového rizika preto pracuje na troch úrovniach: národnej, regionálnej a lokálnej.

\section{Vecný aspekt}

Hlavnou úlohou integrovaného manažmentu povodňového rizika je redukcia povodňového rizika. Viacrozmerné vnímanie povodňového rizika nám umožňuje redukovat' ho v jednotlivých zložkách: ohrození, zranitel'nosti alebo expozícií. Pre aplikáciu komplexného prístupu v celom povodí sa implementujú stratégie na redukciu rizika. Gouldby, Samuels (2005) definujú stratégiu ako kombináciu dlhodobých špecifických ciel’ov, technických opatrení, politických nástrojov a procesov, ktoré sú neustále zosúlad’ované so sociálnym kontextom. Výber stratégie, respektíve výber kombinácie stratégií je podmienený výsledkami hodnotenia povodňového rizika. Implementovat' sa môže:

Stratégia redukcie zaplavenia

Stratégia redukcie zranitel'nosti

Stratégia zmiernenia negatívnych dôsledkov povodní

K naplneniu ciel'ov stratégií slúžia opatrenia, ktoré predstavujú prostriedky na zníženie povodňového rizika. Schanze (2006) rozdeluje opatrenia na intervencie a nástroje. Intervencie sú systémy založené na priamej fyzickej aktivite. Meyer et al. (2012) ich označuje, ako diela vodohospodárskych stavieb. Nástroje sú prostriedky založené na mechanizmoch, ktoré nepriamo ovplyvňujú l'udské chovanie. Prerozdelenie intervencií a nástrojov k príslušným stratégiám nám zobrazuje tab. 1.

\section{Priestorový aspekt}

Zodpovednost' za integrovaný manažment na národnej úrovni sa rozdel'uje medzi ministerstvá, štátne podniky, štátne agentúry a poistovne. Spolu si rozdel'ujú zodpovednost' za tvorbu rámca integrovaného manažmentu povodňového rizika, tvorbu noriem a pravidiel, hodnotenie povodňového rizika na národnej úrovni a poistenie obyvatel'stva proti povodniam. $\mathrm{Na}$ regionálnej úrovni preberajú zodpovednost' samosprávy, správcovia povodí a vodných tokov, záujmové združenia a plánovacie autority. Ich hlavnou úlohou je preniest' normy a regulácie stanovené na národnej úrovni do plánov a stratégií manažmentu povodňového rizika. Nesú zodpovednost' za ochranu pred negatívnymi dôsledkami povodní na svojom území (Hall et al., 2003) a dohliadajú na to aby akcie na lokálnej úrovni 
zodpovedali stratégiám prijatým na regionálnej úrovni (Penning-Rowsell, Priest, 2014).

Tab. 1: Stratégie a k nim príslušné intervencie (šedá) a nástroje (biela). Upravené podla: WMO, GWP, 2004, Harries, Penning-Rowsell (2011)

Table 1: Strategies and related measures (grey) and tools (white). Adapted by: WMO, GWP, 2004, Harries, Penning-Rowsell (2011)

\begin{tabular}{|c|c|}
\hline \multirow{6}{*}{$\begin{array}{l}\text { stratégie na redukciu } \\
\text { zaplavenia }\end{array}$} & Priehrady a vodné nádrže \\
\hline & Hrádze a protipovodňové nábrežia \\
\hline & Odvodňovacie kanály \\
\hline & Manažment povodia \\
\hline & Úprava vodného toku \\
\hline & Zlepšenie odvodnenia \\
\hline \multirow{8}{*}{$\begin{array}{l}\text { stratégie na redukciu } \\
\text { zranitel'nosti voči } \\
\text { poškodeniu }\end{array}$} & Regulácia záplavových území \\
\hline & Zalesňovanie územia \\
\hline & Regulácia využitia pôdy \\
\hline & Vodotesné opatrenia \\
\hline & Vývoj a úprava noriem a regulácii \\
\hline & Návrhy umiestnenia infraštruktúry \\
\hline & Regulácia výstavby domov \\
\hline & Predpovedné systémy a výstrahy \\
\hline \multirow{6}{*}{$\begin{array}{l}\text { stratégie na redukciu } \\
\text { negatívnych dôsledkov } \\
\text { povodní }\end{array}$} & Zvýšenie povedomia verejnosti, vzdelávanie \\
\hline & Tvorba povodňových plánov a plánov evakuácie \\
\hline & Obnova po povodni \\
\hline & Poistenie proti povodniam \\
\hline & Kompenzácia škôd \\
\hline & Prest'ahovanie obyvatel'stva \\
\hline
\end{tabular}

Obce, miestne orgány správy vodných tokov, obyvatelia a stakeholdri predstavujú aktérov lokálnej úrovne. Ich úlohou je poskytovat' informácie pre hodnotenie povodňového rizika. V súlade so stratégiami prijatými na regionálnej úrovni, implementujú opatrenia na lokálnej a individuálnej úrovni.

\section{Nástroje rozhodovania $v$ integrovanom manažmente povodňového rizika}

Povodne sú komplexnou a multidisciplinárnou oblast’ou. V integrovanom manažmente povodňového rizika sa spája viacero záujmov, pričom jedno riešenie ich nemôže obsiahnut'. Dôraz sa teda posúva z návrhu riešení na výber najvhodnejšieho. Proces výberu si vyžaduje, aby boli v rovnakej miere zastúpené všetky skupiny zasahujúce do manažmentu povodňového rizika vrátane ohrozených obyvatel'ov a stakeholdrov. Vyššiu pozornost' treba venovat' 
spravodlivosti a transparentnosti nielen $\mathrm{v}$ alokovaní finančných zdrojov (Bana e Costa et al., 2004), ale aj v „prerozdel'ovaní“ opatrení a nástrojov na ochranu pred negatívnymi účinkami povodní. Posudzovanie vel'kého množstva návrhov z perspektív záujmových skupín je náročný proces a vytvára vel'ký priestor pre rozhodovanie (Jonkman et al., 2003). Pre ul'ahčenie výberu sa využívajú systémy na podporu rozhodovania ( $\mathrm{z}$ angl. decision support systems). Cavallaro, Ciraolo (2005) ich definujú nasledovne: systém na podporu rozhodovania je interaktívny systém, ktorý je schopný produkovat' informácie a údaje a v niektorých prípadoch aj podporovat' porozumenie danej aplikačnej oblasti. Poskytujú pomoc pri riešení zložitého azle definovaného problému. Ich úlohou však nie je vykonávat' rozhodnutia namiesto l'udí, ale poskytnút' podporu a dostatok informácií pre rozhodnutie (Ahmad, Simonovic, 2006).

Najpoužívanejším nástrojom je multikriteriálna analýza (Simonovic, Akter, 2005, Meyer, 2007, Markovic, 2012, Marttunen et al., 2013, Chistaz et al., 2015). Gamper et al. (2006) ju charakterizuje ako metódy a procedúry založené na viacerých protichodných kritériách, ktoré napomáhajú pri rozhodovacom procese. Postup multikriteriálnej analýzy obsahuje osem krokov: definícia problému, určenie hodnotiacich kritérií, stanovenie alternatív, hodnotenie alternatív, váženie kritérií, aplikácia rozhodovacích pravidiel, analýza senzitivity a určenie poradia (Malczewski, 1999, Meyer, 2007).

Definícia problému je základným krokom pri tvorbe rozhodnutí (Mateo, 2012), pričom problém predstavuje rozdiel medzi súčasným a požadovaným stavom. Odstránenie nedostatkov si vyžaduje definovanie ciel'ov na dosiahnutie požadovaného stavu. $\mathrm{V}$ oblasti integrovaného manažmentu povodňového rizika môžeme vybrat' spomedzi redukcie zaplavenia, redukcie zranitel'nosti sociálneho, ekonomického a environmentálneho systému, alebo zmiernenia negatívnych následkov povodní. Špecifikácia ciel'a môže byt' v stanovení počtu ochránených osôb, rozsahu územia, respektíve výšky predídených škôd.

Hodnotenie v multikriteriálnej analýze je založenie na často protichodných kritériách, ktoré predstavujú meratel'ný aspekt rozhodovania, na základe ktorého rozmeru môžeme charakterizovat' posudzované možnosti. Výber kritérií môžeme uskutočnit' na základe viacerých spôsobov. Prvým odporúčaným spôsobom je štúdium a analýza odbornej literatúry, ktorá sa zaoberala podobným problémom akému čelíme (Malczewski, 1999, Meyer, 2007). Druhým spôsobom je výber kritérií na základe preferencií expertov alebo ohrozených obyvatel'ov za pomoci dotazníkového prieskumu alebo delfskej metódy. Tento prístup môžeme vidiet' v práci Haque et al. (2012). Prehl'ad kritérií použitých v rôznych vedeckých prácach uvádzame v tab. 2. Medzi najčastejšie používané kritériá a subkritériá patria: sociálne (vplyv na obyvatel'stvo, verejné zdravie, vnímanie rizika), ekonomické (cena opatrenia, priemerná ročná škoda), environmentálne (vplyv na vodu, pôdu, ekosystémy) a technické (technická zložitost', adaptabilita). 
Tab. 2: Prehl'ad kritérií použitých vo vybraných publikáciách. Upravené podla: Meyer (2007), Foxon et al. (2002)

Table 2: Overview of criteria used in selected publications. Adapted by: Meyer (2007), Foxon et al. (2002)

\begin{tabular}{|c|c|c|}
\hline Publikácia & Kritérium & Subkritérium \\
\hline \multirow{4}{*}{$\begin{array}{l}\text { Meyer } \\
(2007)\end{array}$} & $\begin{array}{l}\text { Economic } \\
\text { (Ekonomické) }\end{array}$ & Anual avarege damage (Priemerná ročná škoda) \\
\hline & $\begin{array}{l}\text { Environmental } \\
\text { (Environmentálne) }\end{array}$ & $\begin{array}{l}\text { Aggregated environmental risk (Agregované } \\
\text { environmentálne riziko) }\end{array}$ \\
\hline & \multirow[b]{2}{*}{ Social (Sociálne) } & AAD (Priemerný počet ovplyvnených osôb ročne) \\
\hline & & $\begin{array}{l}\text { Probability of social hot spors of beign affected } \\
\text { (Pravdepodobnost' ovplyvnenia sociálnych záujmových } \\
\text { skupín) }\end{array}$ \\
\hline \multirow{8}{*}{$\begin{array}{l}\text { Brouver, } \\
\text { Van Ek } \\
(2004)\end{array}$} & $\begin{array}{l}\text { Environmental } \\
\text { (Environmentálne) }\end{array}$ & Nature conservation (Zachovanie prírody) \\
\hline & \multirow{2}{*}{$\begin{array}{l}\text { Economy } \\
\text { (Ekonomické) }\end{array}$} & Costs (Cena) \\
\hline & & Benefits (Výhody) \\
\hline & \multirow{5}{*}{ Social (Sociálne) } & Impact on function (Vplyv na funkciu) \\
\hline & & Perception of landscape change (Vnímanie zmien v krajine) \\
\hline & & Risk perception (Vnímanie rizika) \\
\hline & & Communication efforts (Komunikačné úsilie) \\
\hline & & Particpation possibilities (Možnosti spolupráce) \\
\hline \multirow{16}{*}{$\begin{array}{l}\text { Foxon et al. } \\
(2002)\end{array}$} & \multirow{4}{*}{$\begin{array}{l}\text { Economic } \\
\text { (Ekonomické) }\end{array}$} & Life cycle costs (Dížka životnosti) \\
\hline & & Wilingness to pay (Ochota platit') \\
\hline & & Affordability (Cenová dostupnost') \\
\hline & & Financial risk exposure (Vystavenie finančnému riziku) \\
\hline & \multirow{3}{*}{$\begin{array}{l}\text { Environmental } \\
\text { (Environmentálne) }\end{array}$} & Resources utilization (Využitie zdrojov) \\
\hline & & Service provision (Poskytovanie služieb) \\
\hline & & Environmental impact (Vplyv na životné prostredie) \\
\hline & \multirow{5}{*}{ Social (Sociálne) } & Impact on risks to human health (Vplyv na l'udské zdravie) \\
\hline & & $\begin{array}{l}\text { Acceptability to stakeholders (Prijatel'nost' pre } \\
\text { stakeholderov) }\end{array}$ \\
\hline & & $\begin{array}{l}\text { Participation and responsibility (Spolupráca } \\
\text { a zodpovednost') }\end{array}$ \\
\hline & & $\begin{array}{l}\text { Public awareness and understanding (Verejné povedomie } \\
\text { a porozumenie) }\end{array}$ \\
\hline & & Social inclusion (Sociálna inklúzia) \\
\hline & \multirow{4}{*}{$\begin{array}{l}\text { Technical } \\
\text { (Technické) }\end{array}$} & Performance of the system (Výkonnost' systému) \\
\hline & & Reliability (Spol'ahlivost') \\
\hline & & Durability (Odolnost') \\
\hline & & Flexibility and adaptability (Flexibilita a adaptácia) \\
\hline \multirow{7}{*}{$\begin{array}{l}\text { Bana e } \\
\text { Costa et al. } \\
(2004)\end{array}$} & \multirow{4}{*}{$\begin{array}{l}\text { Environmental } \\
\text { (Environmentálne) }\end{array}$} & Water (Voda) \\
\hline & & Soil (Pôda) \\
\hline & & Fauna and Flora (Fauna a flóra) \\
\hline & & Landscape (Krajina) \\
\hline & \multirow{3}{*}{ Social (Sociálne) } & Perception of flood risk (Vnímanie povodňového rizika) \\
\hline & & Effects on social fabric (Vplyv na sociálne štruktúry) \\
\hline & & Public health (Verejné zdravie) \\
\hline
\end{tabular}




\begin{tabular}{|c|c|c|}
\hline & \multirow{3}{*}{$\begin{array}{l}\text { Technical } \\
\text { (Technické) }\end{array}$} & $\begin{array}{l}\text { Technical complexity of the intervention (Technická } \\
\text { zložitost' zásahu }\end{array}$ \\
\hline & & Complexity of maintenance (Zložitost' údržby) \\
\hline & & Level of Protection (Výška ochrany) \\
\hline \multirow{7}{*}{$\begin{array}{l}\text { De Bruijn } \\
(2005)\end{array}$} & $\begin{array}{l}\text { People } \\
\text { (Obyvatel'stvo) }\end{array}$ & Affected persons (Ovplyvnené osoby) \\
\hline & \multirow{3}{*}{$\begin{array}{l}\text { Economic } \\
\text { (Ekonomické) }\end{array}$} & AAD (Priemerná ročná škoda) \\
\hline & & Costs (Cena) \\
\hline & & Economic opportunities (Ekonomické príležitosti) \\
\hline & \multirow{2}{*}{$\begin{array}{l}\text { Environmental } \\
\text { (Environmentálne) }\end{array}$} & Change in natural area (Zmena v prírodnej oblasti) \\
\hline & & Landscape (Krajina) \\
\hline & $\begin{array}{l}\text { Flexibility } \\
\text { (Flexibilita) }\end{array}$ & \\
\hline
\end{tabular}

Stanovenie alternatív je komplikovaný proces, ktorý vyžaduje tvorivú prácu. Dobrým zdrojom pri tvorbe alternatív je odborná literatúra, ktorá sa zaoberala podobným problémom (DLTR, 2011). Alternatívy by mali byt' otvorené a počas celého procesu multikriteriálnej analýzy by mali byt' upravovatel'né. Takýmto prístupom dospejeme k lepšiemu riešeniu, ktoré je nakoniec aj naším ciel'om (Meyer, 2007, Penning-Rowsell, 2003). Každá oblast' je špecifická a vyžaduje si jedinečný prístup $\mathrm{k}$ riešeniu povodňového rizika. Alternatívy, ktoré navrhujú autori v odbornej literatúre sú preto rôznorodé. Bana e Costa et al. (2004) stanovil tri alternatívy: nerobit' nič, vybudovat' retenčný a sedimentačný priestor a regulovat' korytá vodných tokov, tretia možnost' sa zhodovala s druhou, avšak mala vybudovat' aj park na opatreniach. Brouwer, van Ek (2004) použili nasledovné alternatívy: posilnenie priehrady, zmeny vo využívaní zeme a obnova inundačných území. Kenyon (2007) predstavil až sedem alternatív od rôznych technických opatrení cez zmenu využívania zeme až po odkúpenie všetkých obytných budov. Evers et al. (2012) použil alternatívy: nerobit' nič, technické opatrenie, zmena využívania zeme v povodí a lepšia predpoved', ochrana domov.

Hodnotenie alternatív je proces, v ktorom sa určuje výkon alternatív voči jednotlivým kritériám. Výsledok sa následne vkladá do rozhodovacej matice. Výkon alternatív voči kritériám je možné uskutočnit’ nasledujúcimi spôsobmi:

1. tvorba modelov na predpovedanie efektu opatrení,

2. interview s expertmi poskytujúce ich pohl'ad na záležitost',

3. interview so stakeholdermi a obyvatel'mi,

4. vyhl'adanie analógie v odbornej literatúre.

Dáta jednotlivých kritérií prichádzajú v rôznych mierkach, binárnej, ordinálnej alebo intervalovej. Aby sme s nimi mohli lepšie pracovat' je nutné ich štandardizovat'. Najčastejšie používaná metóda štandardizácie je lineárna transformácia na základe maximálnej hodnoty alebo na základe rozsahu hodnôt.

Ďalší krok, priradenie váh kritériám, je jeden z najdôležitejších. Hlavným účelom tohto kroku je priradenie váh kritériám, tak aby predstavovali ich relatívnu dôležitost' pri rozhodovaní (Zardari et al., 2015). Povodne si vyžadujú zapojenie 
názorov obyvatel'stva, ktoré môže za pomoci svojich zástupcov v procese rozhodovania zdôraznit' určité kritériá. Vo svojich prácach využili názor odborníkov viacerí autori. Chistaz et al. (2015) využil jednoduchý priemer názoru odborníkov a Eigen-vector $\mathrm{z}$ párového porovnávania. Prirad’ovanie váh na workshope stakeholdrov za asistencie bol použitý v práci Marttunen et al. (2013) a Porthin et al. (2013). V samotnom vážení rozoznávame viacero metód. Najpoužívanejšie sú rankingová metóda, metóda rozdelenia bodov a metóda párového porovnávania. Rankingová metóda je najjednoduchšia vážiaca metóda. Jej základom je zoradenie kritérií od najdôležitejšieho po najmenej dôležité. Druhou metódou je rozdelenie bodov, kedy sa rozdeluje stanovený počet bodov medzi kritériá, pričom rozdelenie závisí len od úsudku decision makerov (Zardari et al., 2015). Metóda rozdelenia bodov je presnejšia ako ratingová metóda, nakol'ko umožňuje decision makerom vyjadrit' relatívnu dôležitost' kritéria na intervalovej škále (Meyer, 2007). Metóda párového porovnávania porovnáva každé kritérium voči zvyšným kritériám (Zardari et al., 2015). Na vyjadrenie relatívnej dôležitosti medzi pármi porovnávaných kritérií, sa využíva stupnica od 1 po 9 , kedy jedna predstavuje rovnakú dôležitost' porovnávaných kritérií a 9 absolútnu dominanciu porovnávaného kritéria (Meyer, 2007). Viac o týchto metódach v Zardari et al. (2015). Prehl'ad vedeckých prác s použitými metódami priradenia váh a váženia je v tab. 3 .

Tab. 3: Prehl'ad použitých metód priradenia váh a váženia

Table 3: Overview of assigning weight and weighting methods

\begin{tabular}{|l|c|c|c|}
\hline \multicolumn{1}{|c|}{ Autor } & Priradenie váh & Váženie & Rozhodovacie pravidlá \\
\hline Margeta, Knezic (2002) & Stakeholderi & $\begin{array}{c}\text { Párové } \\
\text { porovnávanie }\end{array}$ & $\begin{array}{c}\text { AHP, PROMETHEE I, } \\
\text { PROMETHEE II }\end{array}$ \\
\hline Brouwer, van Ek (2004) & & Rovnaké váhy & WSM \\
\hline Martin et al. (2007) & Stakeholderi & Rating & ELECTRE III \\
\hline Schumann (2010) & Decision makeri & Rating & TOPSIS, fuzzy AHP \\
\hline Yang et al. (2011) & Stakeholderi & Rating & WSM \\
\hline Evers et al. (2012) & Stakeholderi & Rating & fuzzy TOPSIS \\
\hline Marttunen et al. (2013) & Vol'ba expertov & Rating & MAVT \\
\hline Porthin et al. (2013) & Vol'ba expertov & Rating & WSM \\
\hline $\begin{array}{l}\text { van Loon-Steensma et al. } \\
\text { (2014) }\end{array}$ & Rovnaké váhy & $\begin{array}{c}\text { WSM, CP, VIKOR, TOPSIS, M- } \\
\text { TOPSIS, AHP ELECTRE WSM, } \\
\text { CP, VIKOR, TOPSIS, WSM, CP, } \\
\text { VIKOR, TOPSIS, M-TOPSIS, } \\
\text { AHP ELECTRE I, ELECTRE III }\end{array}$ \\
\hline
\end{tabular}

Účelom aplikácia rozhodovacích pravidiel je zoradenie alternatív na základe hodnotenia alternatív a váh kritérií (Wang et al., 2009). Multikriteriálna analýza sa 
využíva $\mathrm{v}$ rôznych oblastiach rozhodovania, čo podnietilo vznik množstva rozličných metód. Moghaddam et al. (2011) rozdel'uje metódy na elementárne a pokročilé na základe ich zložitosti. Wang et al. (2009) a Zardari et al. (2015) d’alej rozdel'ujú pokročilé metódy podl'a spoločných znakov na metódy multiatribútovej funkčnosti a outrankové metódy. V našej práci predstavíme zástupcu každej triedy. Najčastejšie používanou elementárnou metódou je metóda jednoduchého váženia alebo aj SAW (Simple Additive Weighting Method). Poradie alternatív sa určuje na základe jednoduchého sčítania vážených hodnôt alternatív. Predstavitel’om pokročilých multiatribútových metód je TOPSIS (Technique for Order Preference by Similaritiy to Ideal Solution), ktorá je založená na metóde ideálnych bodov (Malczewski, 1999). Pri tejto metóde sa stanoví ideálna hodnota pre každé kritérium - ideálny bod. Alternatívy sa následne zoradia na základe vzdialenosti od ideálu. Čím menšia vzdialenost' tým vyššie umiestnenie (Chistaz, Banihabib, 2015). Ďalším zástupcom je AHP (Analytical Hierarchy Process) vyvinutý Thomasom L. Saatym v roku 1980 a je najpoužívanejšia v prostredí povodňového rizika (Madruga de Brito, Evers, 2016, Shams et al., 2014). Prvým krokom je tvorba hierarchickej štruktúry problému - dekompozícia. Problém sa „rozloží“ na štyri hierarchické úrovne: hlavný ciel', vedl'ajšie ciele, kritériá a alternatívy. Následne sa vykoná párové porovnávanie (komparatívny úsudok) medzi kritériami a alternatívami. Najznámejšou a najpoužívanejšou metódou spomedzi outrankových metód je ELECTRE (Elimination et Choice Translating Reality), ktorá bola predstavená Benayounom, Royom a Sussmanom v roku 1966 (Wang, 2009). V súčasnosti existuje šest' verzií metódy. Základným princípom všetkých metód skupiny ELECTRE je rozsah, do ktorého hodnotenie alternatív a vážených kritérií potvrdzuje alebo vylučuje dominanciu jednej alternatívy z párového porovnania (Malczewski, 1999).

Predposledným krokom multikriteriálnej analýzy je test senzitivity, ktorý vyhodnocuje robustnost' riešenia. Základom analýzy senzitivity je zmena váh kritérií za účelom zistenia zmeny vo výsledkoch poradia alternatív (EdjossanSossou, 2014). V prípade zachovania výsledkov multikriteriálnu analýzu nemožno pokladat' za objektívnu.

Záver multikriteriálnej analýzy je zoradenie alternatív do poradia podl'a pravidiel rozhodovania. Toto poradie však nemusí byt' pre decision makerov smerodajné, nakol'ko multikriteriálna analýza len ponúka podporu pri rozhodovaní a neponúka rozhodnutie samotné.

\section{Záver}

Integrovaný manažment povodňového rizika predstavuje nový prístup $\mathrm{v}$ redukcii povodňového rizika. Jeho základom je zmena v percepcií povodňového rizika z jednorozmernej koncepcie na viacrozmernú. Redukcia povodňového rizika sa neobmedzuje len na technické opatrenia v blízkosti vodného toku. Presadzuje sa 
komplexný prístup, ktorý pracuje s celým povodím a všetkými dostupnými prostriedkami a inštitúciami. Za účasti miestnych obyvatel'ov a stakeholdrov sa uplatňuje bottom up prístup a zodpovednost' za manažment povodňového rizika sa decentralizáciou prenáša na nižšie hierarchické úrovne. Na redukciu povodňového rizika sa využívajú komplexné stratégie určené pre celé povodie, ktoré pozostávajú z konkrétnych opatrení technického alebo inštitucionálneho charakteru. V rámci priestorového aspektu rozdel'uje manažment svoju zodpovednost' na národnú, regionálnu a lokálnu úroveň, medzi paletu aktérov z verejnej správy, tretieho sektora a obyvatel'ov.

Pre výber najvhodnejšieho opatrenia na redukciu povodňového rizika je najčastejšie využívaná multikriteriálna analýza, ktorá ponúka podporu pri rozhodovaní za použitia rôznych, často protichodných, kritérií. Často využíva preferencie decision makerov a stakeholdrov pri získavaní váh jednotlivých kritérií a viaceré rozhodovacie pravidlá, ktoré dokážu pracovat' aj s neurčitými hodnoteniami.

\section{Literatúra}

AHMAD, S. - SIMONOVIC, S. 2006. An Intelligent Decision Support System for Management of Floods. In Water Resources management. ISSN 1573-1650, 2006, vol. 20, no. 3, pp. 391-410.

BANA E COSTA, A. - ANTAI DA SILVA, P. - CORREIA, N. F. 2004. Multicriteria Evaluation of Flood Control Measures: The Case of Riberia do Livramento. In Water Resources management. ISSN 1573-1650, 2004, vol. 18, no. 3, pp. 263-283.

BOUMA, J. J. - FRACOIS, D. - TROCH, P. 2005. Risk assessment and water management. In Environmental Modeling \& Software. ISSN 1364-8152, 2005, vol. 20, no. 2, pp. 141-151.

BROUWER, R. - VAN EK, R. 2004. Integrated ecological, economic and social impact assessment of alternative flood control policies in the Netherlands. In Ecological Economics. ISSN 0921-8009, 2004, vol. 50, no. 1, pp. 1-21.

CAVALLARO, F. - CIRAOLO, L. 2005. A multicriteria approach to evaluate wind energy plants on an Italian Island. In Energy Policy. ISSN 0301-4215, 2005, vol. 33, no. 2, pp. 235-244.

DE BRUIJN, K. M. 2005. Resilience and flood risk management. In Water Policy. ISSN 1366-7017, 2005, vol. 6, no. 1, pp. 53-66.

DIEPERNIK, C. - GREEN, C. - HEGGER, D. - DRIESSEN, P. - BAKKER, M. - CRABBE, A. - EK, K. 2013. Flood Risk Management in Europe: An exploration of Governance Challenges. STAR-FLOOD Consortium, Utrecht, The Netherlands, 2013.9 p. ISBN 978-94-91933-03-5. 
DODGSON, J. - SOACKMAN, M. - PEARMAN, A. - PHILLIPS, L. 2001. DTLR multi-criteria analysis manual. National Economic Research Associates, London, 2001. $145 \mathrm{p}$.

EDJOSSAN-SOSSOU, M. A. - DECK, O. - HEIB, A. M. - VEDEL, T. 2014. A decision-support methodology for assessing the sustainability of natural risk management strategies in urban areas. In Natural Hazards and Earth System Sciences. ISSN 1561-8633, 2014, vol. 14, no. 12, pp. 3207-3230.

ESTMAN, R. - EMANI, S. - HULINA, S. - JIANG, H. - JOHNSON, A. RAMACHANDRAN, M. 1997. Applications of Geographic Information Systems (GIS) Technology in Environmental Risk Assessment and Management. UNEP, Division of Environmental Information and Assessment, Sioux Falls, SD.

EVERS. M. - JONOSKI, A. - ALMORADIE, A. - LANGE, L. 2012. Collaborative modelling for active involvement of stakeholders in urban flood risk management. In Natural hazards and Earth System Sciences. ISSN 15618633, 2012, vol. 91, pp. 95-110.

FILHO. L. W. 2003. Climate Change and Disaster Risk Management. Hamburg: Springer, 2003. 692 p. ISBN 978-3-642-31110-9.

FOXON, T. J. - MCILKENNY, G. - GILMOUR, D. - OLTEAN-DUMBRAVA, C. - SOUTER, N. - ASHLEY, R. - BUTTLER, D. - PEARSON, P. JOWITT, P. - MOIR, J. 2002. Sustainability Criteria for Decision Support in the UK Water Industry. In Journal of Environmental Planning and Management. ISSN 1360-0559, 2002, vol. 45, no. 2, pp. 285-301.

GAMPER, C. - THONI, M. - WECK-HANNEMANN, H. 2006. A conceptual approach to the use of Cost Benefit analysis and Multi Criteria analysis in natural hazard management. In Natural Hazards Earth System Science. ISSN 1561-8633, 2006, vol. 6, no. 2, pp. 293-302.

GOULDBY. B. - SAMUELS, P. 2005. Language of risk - project definitions. Floodsite project report T32-04-01 [online] 2005 [cit. 15. 1. 2017]. Dostupné na internete: http://www.floodsite.net/html/partner_area/project_ docs/floodsite _language_of_risk_v4_0_p1.pdf

HALL, W. J. - MEADOWCROFT, C. I. - SAYERS, B. P. - BRAMLEY, E. M. 2003. Integrated Flood Risk Management in England and Wales. In Natural Hazards Review. ISSN 1527-6996, 2003 vol. 4, no. 3, pp. 126-135.

HALL, J. - PENNING-ROWSELL, E. 2011. Setting the Scene for Flood Risk Management. In Flood Risk Science and Management. Oxford: WileyBlackwell, 544 p. ISBN 978-1-405-18657-5.

HAQUE, A. N. - GRAFAKOS, S. - HUIJSMAN, M. 2012. Participatory integrated assessment of flood protection measures for climate adaptation in Dhaka. In Environment \& Urbanization. ISSN 1746-0301, 2012, vol. 24, no. 1, pp. 197-123.

HARRIES, T. - PENNING-ROWSELL, E. 2011. Victim pressure, institutional 
inertia and climate change adaptation: The case of flood risk. In Global Environmental Change. ISSN 0959-3780, 2011, vol. 21, no. 1, pp. 188-197.

CHISTAZ, N. - BANIHABIB, M. 2015. Comparison of Different Multi Criteria Decision-Making Models in Prioritizing Flood Management Alternatives. In Water Resources Management. ISSN 1573-1650, 2015, vol. 29, no. 8, pp. 2503-2525.

IPCC. 2012. Managing the Risks of Extreme Events and Disasters to Advance Climate Change Adaptation. A Special Report of Working Groups I and II of the Intergovernmental Panel on Climate Change. Cambridge University Press, Cambridge, UK; New York, NY, USA, 582 p. ISBN 978-1-107-02506-6.

JONKMAN, N. - VAN GELDER, M. J. A. H. P. - VRIJLING, K. J. 2003. An overview of quantitative risk measures for loss of life and economic damage. In Journal of Hazardous Materials. ISSN 0304-3894, 2033, vol. 99, no. 1, pp. 130.

KENYON, W. 2007. Evaluating flood risk management options in Scotland: A participant-led multi-criteria approach. In Ecological Economics. ISSN 0921-8009, 2007, vol. 64, no. 1, pp. 70-81.

KOKS, E. E. - JONGMAN, B. - HUSBY, G. T. - BOTZEN, W. J. W. 2015. Combining hazard, exposure and social vulnerability to provide lessons for flood risk management. In Environmental Science \& Policy. ISSN 1462-9011, 2015, vol. 47, pp. 42-53.

KOUSKY, C. - WALLS, M. 2014. Floodplain conservation as a flood mitigation strategy: Examining costs and benefits. In Ecological Economics. ISSN 09218009. 104, s. 119-128.

MADRUGA DE BRITO, M. - EVERS, M. 2016. Multi-criteria decision-making for flood risk management: a survey of the current state of the art. In Natural Hazards Earth System Sciences. ISSN 1561-8633, 2016, vol. 10, no. 4, pp. 509527.

MALCZEWSKI, J. 1999. GIS and multicriteria decision analysis. New York: Wiley, 1999. 408 p. ISBN 978-0-471-32944-2.

MARGETA, J. - KNEZIC, S. 2002 Selection of the flood management solution of Karstic Field. In Water International. ISSN 1941-1707, 2002, vol. 27, no. 3, pp. 431-441.

MARKOVIC, M. 2012. Multi criteria Analysis of Hydraulic Structures for River Training Works. In Water resources Management. ISSN 1573-1650, 2012, vol. 26, no. 13, pp. 3893-3906.

MARTIN, C. - RUPERD, Y. - LEGERT, M. 2007. Urban stormwater drainage management: the development of a multicriteria decision aid approach for best management practices. In European Journal of Operational Research. ISSN 0377-2217, 2007, vol. 181, no. 1, pp. 338-349.

MARTTUNEN, M. - MUSTAJOKI, J. - DUFVA, M. - KARJALAINEN, P. T. 2013. How to design and realize participation of stakeholders in MCDA 
processes? A framework for selecting an appropriate approach. In EURO Journal on Decision Processes. ISSN 2193-9446, 2013, vol. 3, no.1-2, pp. 287214.

MATEO, J. 2012. Multi-Criteria Analysis in the Renewable Energy Industry. London: Springer, 2012. 105 p. ISBN 978-1-4471-2346-0.

MCFADDEN, L. - PENNING-ROWSELL, E. - TAPSELL, S. 2009. Strategic coastal flood-risk management in practice: Actors' perspectives on the integration of flood risk management in London and the Thames Estuary. In Ocean \& Coastal Management. ISSN 0964-5691, 2009, vol. 52, no. 12, pp. 636-645.

MERZ, B. - KREIBICH, H. - SCHWARZE, R. - THIEKEN, A. 2010. Fluvial flood risk management in a changing world. In Natural Hazards Earth System Science. ISSN 1561-8633, 2010, vol. 10, no. 3, pp. 509-527.

MEYER, V. 2007. GIS-based Multicriteria Analysis as Decision Support in Flood Risk Management. In UFZ-Diskussionspapiere. vol. 6, pp. 57.

MEYER, V. - PRIEST, S. - KUHLICKE, CH. 2012. Economic evaluation of structural and non-structural flood risk management measures: examples from the muddle river. In Natural Hazards. ISSN 1573-0940, 2012, vol. 62, no. 2, pp. 301-324.

MOGHADDAM, N. B. - NASIRI, M. - MOUSAVI, M. S. 2011. An appropriate multiple criteria decision making method for solving electricity planning problems, addressing sustainability. In International Journal of Environmental Science \& Technology. ISSN 1735-2630, 2011, vol. 8, no. 3, pp. 605-620.

PORTHIN, M. - ROSQVIST, T. - PERRELS, A. - MOLARIUS, R. 2013. Multicriteria decision analysis in adaptation decision-making: a flood case study in Finland. In Regional Environmental Change. ISSN 1436-378X, 2013, vol. 13, no. 6, pp. 1171-1180.

PENNING-ROWSELL, E. 2003. Flood as Catalysts for Policy Change: Historical Lessons from England and Wales. In International Journal of Water Resources Development. ISSN 1360-0648, 2003, vol. 21, no. 4, pp. 561-575.

PENNING-ROWSELL, E. - PRIEST, S. 2014. Sharing the burden of increasing flood risk: who pays for flood insurance and flood risk management in the United Kingdom. In Mitigation and Adaptation Strategies for Global Change. ISSN 1573-1596, 2014, vol. 20, no. 6, pp. 991-1009.

SHAMS, F. - MOHAMED, S. - FAYEK, A. R. 2014. Improving consistency evaluation in fuzzy multi-attribute pairwise comparison based decision-making methods. In Asia-Pacific Journal of Operational Research. ISSN 1793-7019, 2014, vol. 31, no. 4.

SCHANZE, J. 2006. Flood risk management - a basic framework. In Flood Risk Management: Hazards, Vulnerability and Mitigation Measures. Springer: Dordecht, 2006. 309 p. ISBN 978-1-4020-45998-1.

SCHUMANN, H. A. - NIJSSEN, D. - PAHLOW, M. 2010. Handling 
uncertainties of hydrological loads in flood retention planning, In International Journal of River Basin Management. ISSN 1814-2060, 2010, vol. 8, no. 3-4, pp. 281-294.

SIMONOVIC, S. - AKTER, T. 2005. Aggregation of fuzzy views of a large number of stakeholders for multi-objective flood management decisionmaking, In Journal of Environmental Management. ISSN 0301-4797, 2005, vol. 77, no. 2, pp. 133-143.

SOLÍN, L. 2015. Recent Slovak flood protection relative to integrated flood risk management. In International Journal of River Basin Management. ISSN 18142060, 2015, vol. 13, no. 4, pp. 463-473.

VAN LOON-STEESMA, M. J. - SCHELFHOUT, A. H. - VVELLINGA, P. 2014. Green adaptation by innovative dike concepts along the Dutch Wadden Sea coast. In Environmental Science \& Policy. ISSN 1462-9011, 2014, vol. 44, no. 1 , pp. 108-125.

WANG, J. J. - JING, Y. Y. - ZHANG, CH. - HHAO, J. 2009. Review on multicriteria decision analysis aid in sustainable energy decision-making. In Renewable and Sustainable Energy Reviews. ISSN 1364-0321, 2009, vol. 13, no. 9 , pp. 2263-2278.

WEHN, U. - RUSCA, M. - EVERS, J. - LANFRANCHI, V. 2015. Participation in flood risk management and the potential of citizen observatories: A governance analysis. In Environmental Science \& Policy, ISSN 1462-9011, 2015, vol. 48, pp. 225-236.

WMO, GWP. 2004. Integrated flood Management. APFM Technical Documents No. 1. 2004. World Meteorological Organization and Global Water Partnership, Geneva. 28 p.

YANG, M. - QIAN, X. - ZHANG, Y. - SHENG, J. - SHEN, D. - GE, Y. 2011. Spatial Multicriteria Decision Analysis of Flood Risks in Aging-Dam Management in China: A Framework and Case Study In Environmental Research and Public Health. ISSN 1660-4601, 2011, vol. 8, no. 5, pp. 13681387.

ZARDARI, H. - AHMED, K. - SHIRAZI, S. - M., YUSOP, Z. B. 2015. Weighting Methods and their Effects on Multi-Criteria Decision Making Model Outcomes in Water Resources Management. London: Springer, 2015. 172 p. ISBN 978-3-319-12586-2.

\section{USING MULTI-CRITERIA ANALYSIS IN INTEGRATED FLOOD RISK MANAGEMENT}

\section{Summary}

The massive flood damage has highlighted the fact that a one-dimensional perception of flood risk is insufficient because flood protection has failed. The 
damage was not caused by the flood itself, but by the vulnerability of objects in hazard. The new aspect of vulnerability in combination with flood hazard and exposition formed the new multidimensional concept of flood risk. Different approach to flood opened door to integrated flood risk management, which is based on new value system of society with emphasis on protection of ecosystems, decentralization of responsibility for streams, management of flood risk and proactive involvement of public in the decision process.

Integrated flood risk management is a holistic approach that involves not only other scientific disciplines but mainly public administration institutions, the third sector, residents at risk and stakeholders. Residents are involved in providing information to flood risk assessment, providing their opinion on how to address the issue of flooding and engaging in decision-making to find the most appropriate solution. Decentralization is another important principle. Responsibility for management of flood risk reduction is transferred to the local level and great emphasis is put on the individual responsibility of the population at risk. One of three strategies or their combination is applied to reducing flood risk. For each strategy, structural or non-structural measures are in place. Responsibility for flood risk is divided into three hierarchical levels: national, regional and local. The actors at each level are assigned tasks such as: creating a comprehensive framework for integrated flood risk management (national level), developing river basin strategies (regional level), selecting and implementing measures, resident and stakeholder's participation (local level).

The selection of the most appropriate measure at the local level requires the inclusion of the opinion of residents and stakeholders but also a transparent and equitable distribution of financial resources as well as flood risk mitigation. For this purpose, decision support systems are used. The most frequently used tool is a multi-criteria analysis that provides decision support based on multiple, often contradictory criteria. Multi-criteria analysis consists of eight steps: definition of the problem, determination of evaluation criteria, determination of alternatives, evaluation of alternatives, criteria weighing, application of decision-making rules, sensitivity analysis and ranking. In the first step, we define the problem, the difference between the current and the desired state. Subsequently, the evaluation criteria are selected, which can be done based on a study of literature or with the help of decision makers or residents. The selection of alternatives is a complex and creative process, since each situation has different conditions and type of flood risk. Assessment of alternatives against criteria can be based on models, expert opinions, opinion of the population, or analogy in the literature. The next step, weighing the criteria, show the preferences of the decision makers to the criteria. Criteria, alternatives, and criteria weights are then combined based on decisionmaking rules. The entire process is then subjected to a sensitivity analysis, which detects whether there are different results when changing the parameters of one of the steps. The last step is to sort the alternatives based on the results. 


\section{Mgr. Lukáš Michaleje}

Geografický ústav SAV

Štefánikova 49, 81473 Bratislava

E-mail: geoglumi@savba.sk 